\title{
Efficiency Barriers to the Consolidation of the European Financial Services Industry
}

\author{
Allen N. Berger \\ Board of Governors of the Federal Reserve System \\ Washington, DC 20551 U.S.A. \\ and \\ Wharton Financial Institutions Center \\ Philadelphia, PA 19104 U.S.A. \\ aberger@frb.gov \\ Robert DeYoung \\ Federal Reserve Bank of Chicago \\ Chicago, IL 60604 U.S.A. \\ robert.deyoung@chi.frb.org \\ Gregory F. Udell \\ Kelley School of Business, Indiana University \\ Bloomington, IN 47405 U.S.A. \\ gudell@indiana.edu
}

\begin{abstract}
Cross-border consolidation of financial institutions within Europe has been relatively limited, possibly reflecting efficiency barriers to operating across borders, including distance; differences in language, culture, currency, and regulatory/supervisory structures; and explicit or implicit rules against foreign competitors. EU policies such as the Single Market Programme and European Monetary Union attenuate some but not all of these barriers. The evidence is consistent with the hypothesis that these barriers offset most of any potential efficiency gains from cross-border consolidation. Banks headquartered in other EU nations have slightly lower average measured efficiency than domestic banks and non-EU-based foreign banks.
\end{abstract}

Forthcoming, European Financial Management 6 (2000)

JEL classification codes: G21, G22, G24, G28, G34, F23

Key words: Banks, Mergers, Efficiency, Europe, Financial institutions.

The opinions expressed do not necessarily reflect those of the Federal Reserve Board, the Federal Reserve Bank of Chicago, or their staffs. The authors thank John Doukas and Glenn Hoggarth for helpful suggestions and Kelly Bryant for outstanding research assistance.

Please address correspondence to Allen N. Berger, Mail Stop 153, Federal Reserve Board, 20th and C Sts. NW, Washington, DC 20551, call 202-452-2903, fax 202-452-5295, or email aberger@frb.gov. 


\section{Introduction}

The European financial services industry is becoming substantially more consolidated as financial institutions engage in merger and acquisition (M\&A) activity within individual European nations, among the nations of the continent, and with institutions in non-European nations. For example, between 1990 and 1997, the total number of credit institutions in France fell by 33\% from 779 to 519. Other major European nations had similar consolidation over this interval, with the numbers of credit institutions in Germany, Italy, the Netherlands, Switzerland, and the U.K. falling by $26 \%, 12 \%, 17 \%, 21 \%$, and 13\%, respectively (Bank for International Settlements data).

There are a number of potential driving forces behind this consolidation. Financial institution managers may have been engaging in M\&A activity in order to improve efficiency or increase market power in response to shareholder demands to maximize value. In cases in which corporate control mechanisms are weak, managers may have also been pursuing their own goals of empire-building, compensation, or expense preference through consolidation. The acceleration of financial services consolidation in recent years may be due to technological progress, improvements in financial condition, accumulation of excess capacity or financial distress, international consolidation of markets, or deregulation. These worldwide causes of consolidation and the reasons for the recent acceleration have been detailed elsewhere (e.g., Berger, Demsetz, and Strahan 1999).

It might have been expected that international consolidation of financial institutions would be especially rapid across national boundaries in the EU, where the removal of restrictions on cross-border entry and the harmonization of regulatory and supervisory environments were intended to make it relatively easy for managers to cross international boundaries. The sequence of legal changes since the 1970s that has made it more possible and less costly for financial institutions to operate across borders within the EU is often referred to as the Single Market Programme. One of these changes, the Second Banking Co-ordination Directive of 1989, introduced a single banking license valid throughout the EU; limited branching and product mix restrictions to those imposed by a bank's home country regulators; and harmonized capital requirements, among other changes. Implemented in 1993 and 1994, the Second Directive made universal banking the norm in the EU by default, since any nation not allowing these powers put its own institutions at a competitive disadvantage. Additional EU directives were 
aimed to achieve a European single securities market and to establish a 'single passport' for investment firms. The implementation of the European Monetary Union may also be expected to complement the EU directives for the participating nations and increase cross-border consolidation by improving trade, by reducing the currency conversion costs of institutions operating in multiple nations, and by lowering the costs to consumers and businesses of purchasing services from foreign institutions.

As the name suggests, one of the intentions of the Single Market Programme was to create a single, efficient market for financial services in the EU. Cross-border competition would arguably improve efficiency and reduce market power, inducing prices to converge and fall to the level of the most efficient producers (see the Cecchini study, Commission of the European Communities 1988a,b). However, research on changes in prices and market power have generally suggested only a modest impact (e.g., Molyneux, Lloyd-Williams, and Thornton 1994, European Commission 1997, Bikker and Groeneveld 1998, Cerasi, Chizzolini, and Ivaldi 1998). Moreover, there has generally been more domestic consolidation within individual European nations than international consolidation across European nations, which may be surprising given the efforts of theEU to create a single market. For example, most of the very largest bank M\&As announced in Europe in recent years -- such as the UBS-Swiss Bank Corp., BNP-Paribas, Royal Bank of Scotland-National Westminster M\&As (as well as the ill-fated Deutsche Bank-Dresdner Bank M\&A) -- primarily would increase concentration within a single nation.

In this paper, we argue that there may be efficiency barriers that limit the amount of international consolidation of financial institutions within Europe and inhibit the creation of a single EU market. These barriers refer to factors that make it difficult to own and operate a financial institution in another nation, including problems of managing and monitoring institutions from a distance; differences in language, culture, currency, and regulatory/supervisory structures across nations; and explicit or implicit rules against foreign competitors. The Single Market Programme and European Monetary Union reduce some but not all of these barriers for EU nations and for the subset participating in monetary union, respectively, but the remaining barriers may make it difficult to move substantially towards a consolidated EU market for financial services. While efficiency is not the only consideration behind M\&A decisions, consolidation across international borders is likely to be significantly limited in our opinion if foreign-based institutions are not able to take advantage of potential efficiency gains 
from this consolidation. The available research results suggest that in most cases they may not be able to do soin most of the EU markets studied, banks headquartered in other EU nations have about the same or slightly lower measured profit efficiency on average than domestic banks and non-EU-based banks.

Section 2 provides some data on European consolidation of large commercial banks, securities firms, and insurance companies, broken down by the geographic location and the main financial service lines of the acquirer and target firms. Section 3 reviews the extant empirical research on a number of different efficiency effects of consolidation that may apply to either domestic or international M\&As, including several types of scale, scope, and X-efficiency effects. Section 4 examines the available evidence on barriers to efficiency gains from international consolidation, and Section 5 gives a brief summary.

\section{Data on European financial consolidation}

Table 1 summarizes some data on M\&As of large, publicly traded financial institutions in Europe over the period 1985-1997. The values shown are the sums of the market values in U.S. dollars of the target institutions over the period, and the percentages of activity within each panel they represent. Panel A reports the flow of domestic M\&A activity within individual European nations, Panel B gives information on cross-border M\&As within Europe, and Panel C shows the corresponding data for international M\&As between European and non-European financial institutions. The data for acquiring and target institutions are broken out by the main financial service line of the financial service firm -- commercial banking, securities, or insurance -- giving nine types of financial service M\&As for each panel.

Several stylized facts emerge from inspection of Table 1. First, despite the Single Market Programme, cross-border M\&As of financial institutions within Europe are smaller in market value terms than domestic M\&As within individual European nations. For all but a few of the nine cases, domestic M\&A activity is several times greater than intra-Europe international activity of the same type. This suggests that at least in terms of the market for corporate control, the players did not consider Europe to be a single market over this time interval, but rather conducted more of their consolidation activities within a single country.

Second, despite the universal banking norm in the EU as set forth by the Second Directive, most of the M\&A activity was "simple" consolidation between institutions with the same main financial service line. This "simple" consolidation is represented on the diagonals of each of the $3 \times 3$ matrices, and "universal-type" 
consolidation between institutions with different main service lines is represented by the off-diagonal elements. The value of the simple M\&As exceeds the value of the universal-type M\&As in all three panels - domestic M\&As, intra-Europe international M\&As, and intercontinental M\&As involving European institutions. While many institutions in Europe were and continue to be universal institutions offering many types of services, there does not appear to be an overwhelming movement towards conglomeration of different types of services.

Third, there are substantial differences in the domestic versus international character of M\&As by type of financial institution. Within the simple type of consolidation between institutions with the same main service line, commercial banks-consolidating-with-other-banks is the most voluminous form of domestic M\&A activity, while insurance companies-consolidating-with-other-insurers is more voluminous than bank M\&As in both international consolidation groups. We also note that domestic simple commercial bank M\&As dominate international simple bank M\&As, whereas the total international simple insurance M\&As (sum of Intra-Europe and Europe-Non Europe international M\&As) dominate domestic simple insurance M\&As. For simple securities M\&As, domestic and international M\&A volumes are approximately equal. These data are consistent with the hypothesis that that there may be differences in the degree of efficiency barriers to international consolidation by financial service line of business. The greater international M\&A activity of insurance companies relative to commercial banks could be explained by efficient insurance managers being better able to overcome cross-border efficiency barriers and operate relatively efficiently in many nations. However, such a conclusion would be highly speculative, as we are not aware of any direct efficiency evidence on this point.

\section{The efficiency effects of consolidation}

There are a number of different potential efficiency effects of consolidation that may apply to either domestic or international M\&As. In this section, we review the extant empirical research on a number of these types of efficiency. We include the scale and scope efficiency effects of M\&As that increase the size and number of different types of services offered by the consolidated institutions. We also include several X-efficiency effects, or changes that move the consolidating institutions closer to or further from their optimal points on the best-practice efficient frontier. Specifically, we consider the X-efficiency effects of geographic diversification and managing from a distance, and the X-efficiency consequences of the M\&A process itself. For all of these types of efficiency, we consider both cost and revenue efficiency effects, and often include research on profit efficiency, 
which incorporates both cost and revenue efficiency. For some of the types of efficiency, a change in the risks of consolidating institutions is also a consideration, because the risk of the consolidated institution affects its costs of funds and its ability to raise revenues. The research is drawn from many countries, including most of the European nations, although most of the studies use U.S. data. ${ }^{1}$

\subsection{Scale efficiency effects of consolidation}

Consolidation increases the size of financial institutions, which may have cost or revenue efficiency effects. Most of the research on financial institution cost scale efficiency used data from the 1980s found that the average cost curve had a relatively flat U-shape with medium-sized institutions being slightly more cost scale efficient than either large or small institutions (e.g., Berger, Hanweck, and Humphrey 1987, Goldberg, Hanweck, Keenan, and Young 1991, Cummins and Zi 1998). However, some recent research using data from the 1990s suggests that there may be substantial cost scale economies even at larger institution sizes, possibly due in part to technological progress (Berger and Mester 1997).

Revenue scale economies may occur because some customers may need or prefer the services of larger institutions. To the extent that larger portfolios result in improved risk diversification, there may also be revenue scale economies because customers place higher value on financial guarantees, such as loan commitments or derivative contracts issued by safer institutions. Any improvement in risk diversification may also increase the opportunity to engage in higher risk-higher expected return activities because of reduced pressure from market participants and government supervisors and regulators.

A few studies have examined the effects of financial institution scale on revenue efficiency or profit efficiency (which incorporates both cost and revenue efficiency). The scale results are ambiguous, with some evidence of diseconomies and some evidence of economies of scale (e.g., Berger, Hancock, and Humphrey 1993, Berger, Humphrey, and Pulley 1996, Clark and Siems 1997, Cummins and Weiss 2000).

\subsection{Scope efficiency effects of consolidation}

Consolidation may also have scope efficiency effects, particularly if the M\&A is of the universal type, combining institutions with different main lines of financial services. The relatively few studies of cost scope efficiencies associated with universal banking in Europe are mixed - one study found very small scope

\footnotetext{
${ }^{1}$ For a detailed survey of research on the efficiency of financial institutions, see Berger and Humphrey (1997).
} 
economies (Allen and Rai 1996), one study found some limited evidence of economies (Vander Vennet 1999), and one study found mostly diseconomies (Lang and Welzel 1998). The research on cost scope and product mix economies of providing different combinations of services within a single type of financial institution yielded mixed results as well (e.g., Berger, Hanweck, and Humphrey 1987, Goldberg, Hanweck, Keenan, and Young 1991, Mester 1993, Berger, Cummins, Weiss, and Zi 2000).

Universal-type consolidation may also have revenue scope efficiency effects, depending upon whether customers prefer and are willing to pay more for the convenience of one-stop shopping for financial services versus preferring and paying more for the more tailored services that might be provided by specialists. One study of European universal banks found that they typically had both higher revenues and higher profitability than specializing institutions (Vander Vennet 1999). There may also be revenue and cost scope economy effects from the changes in risk associated with universal-type consolidation. One study of combining commercial banking and insurance companies in the U.K. found favorable results (Llewellyn 1996). Studies that evaluated the likely effects of combining different types of U.S. financial institutions found mixed results (e.g., Boyd, Graham, and Hewitt 1993, Saunders and Walter 1994, Kwan 1998). The research on the revenue and profit economies of providing different combinations of services within a single type of financial institution yielded mixed results as well (e.g., Berger, Humphrey, and Pulley 1996, Berger, Hancock, and Humphrey 1993, Berger, Cummins, Weiss, and $\mathrm{Zi} 2000)$.

\subsection{The X-efficiency effects of geographic diversification}

Geographic expansion may improve efficiency by diversifying risks because the returns on loans, securities, insurance policies, and other financial instruments issued in different locations may have relatively low or negative correlations. Improved diversification may increase cost efficiency by reducing risk premiums on debt from solving informational opacity problems, lowering the expected costs of financial distress, and/or lessening the costs of prudential regulation and supervision. Similar to diversification by size, improved geographic diversification may also increase revenue efficiency by enhancing the value of financial guarantees or the opportunity to make higher risk-higher expected return investments because of reduced pressure from market participants and government supervisors. Consistent with this, empirical research using U.S. data generally found that larger, more geographically diversified institutions tend to have better risk-expected return tradeoffs (e.g., 
McAllister and McManus 1993, Hughes, Lang, Mester, and Moon 1996, Cummins and Weiss 2000). It may be expected that gains from diversification would be even greater for consolidation across international borders within Europe, given that correlations of bank earnings across European nations were found be very low relative to correlations of bank earnings across regions in the U.S. (Berger, DeYoung, Genay, and Udell 2000).

\subsection{The $\mathrm{X}$-efficiency effects of managing from a distance}

Possibly either augmenting or offsetting the effects of geographic diversification, there may be efficiency difficulties with geographical expansion in part because of organizational diseconomies to operating or monitoring an institution from a distance. These may include turf battles between staff in different locations, high costs and turnover in getting upper level managers to move, monitoring problems in evaluating the behavior and effort of managers in a distant market, difficulty in maintaining customer relationships, etc.. These difficulties may be manifested as higher costs of providing the same financial services or as lower revenues from problems in providing the same perceived or actual quality and variety of services as local institutions. However, it is also possible that some efficiently managed institutions are able to overcome these geographic disadvantages and operate more efficiently than locally-based institutions in other markets. One study of cross-regional banking in the U.S. found that the efficiency advantages and disadvantages of geographic expansion approximately cancel each other out (Berger and DeYoung 2000). Consolidation across international borders also has important geographic efficiency considerations, as discussed in Section 4 below.

\subsection{The X-efficiency effects of the M\&A process}

M\&As are dynamic events that often involve changes in organizational focus or managerial behavior that may change the X-efficiency of the organizations. X-efficiency may be improved if the acquiring institution is more efficient ex ante and brings the efficiency of the target up its own level, if the M\&A awakens management to the need for improvement or is used as an excuse to implement politically difficult cost-cutting or restructuring. Alternatively, X-efficiency be worsened because of the costs of consummating the M\&A, disruptions from the integration process, or organizational diseconomies to operating or monitoring a more complex institution.

Studies of U.S. financial institutions generally showed very little or no cost X-efficiency improvement on average from M\&As although the benefits appear to have been greater for nonbank institutions (e.g., Berger and Humphrey 1992, Rhoades 1998, Cummins, Tennyson, and Weiss 1999, Fried, Lovell, and Yaisawarng 1999). 
Studies of M\&As of credit institutions throughout Europe were mixed (Vander Vennet 1996,1998), but studies of Italian banks (Resti 1998) and U.K. building societies (Haynes and Thompson 1999) found significant cost efficiency gains following M\&As. Studies of profit X-efficiency using U.S. data often found more gains from M\&As, and these were generally linked to improved diversification of risks that allowed the institutions to engage in higher risk-higher expected return activities, such as additional commercial loans (Akhavein, Berger, and Humphrey 1997, Berger 1998, Hughes, Lang, Mester, and Moon 1999).

The change in the total market value of the acquiring plus the target institution (adjusted for changes in overall stock market values) after an M\&A announcement embodies the present value of expected future changes in both efficiency and market power. The empirical results for U.S. data are mixed, with some studies finding increases in value for some types of M\&As (e.g., Hannan and Wolken 1989, Cornett and Tehranian 1992, Houston and Ryngaert 1994). One study found that cross-border M\&As involving U.S. banks created more value than domestic M\&As (DeLong 1999). Some limited evidence also suggests that European financial service M\&As increase combined value (van Beek and Rad 1997, Cybo-Ottone and Murgia 1998).

\subsection{Implications of the research on the efficiency effects of consolidation}

The research reviewed in this section clearly suggest that there is a substantial potential for efficiency gains from financial services industry consolidation in Europe. The potential for cross-border consolidation within Europe to improve efficiency through risk diversification appears to be especially great, based on the relatively low correlations of bank earnings across European nations. As discussed, risk diversification from geographic expansion may increase cost efficiency by reducing risk premiums on debt or lessening the costs of prudential supervision/regulation and may increase revenue efficiency by enhancing the value of financial guarantees issued by the institutions and creating the opportunity to make higher risk-higher expected return investments. Most of the benefits to U.S. M\&As appear to be in the form of higher revenues attributable to taking advantage of such opportunities.

However, it is unclear how much of this potential for European efficiency gains may be achieved. Most of the prior research (primarily based on U.S. experience) suggests that only a small part of the potential efficiency gains from consolidation tend to be achieved. In addition, as discussed in the next section, there may be barriers to achieving efficiency gains by owning and operating financial institutions in other nations, even within 
EU nations where many of these barriers have been reduced.

\section{Evidence on barriers to efficiency gains from international consolidation}

The consolidation of financial institutions across international borders may have any or all of the scale, scope, and X-efficiency effects described in Section 3, but these may still not tell the entire story. In addition to the difficulty of managing and monitoring institutions from a distant headquarters (discussed earlier), financial institutions that own and operate institutions in foreign nations may face a number of other barriers to running these institutions efficiently. Additional efficiency barriers may include differences in language, culture, currency, and regulatory/supervisory structures; and explicit or implicit rules against foreign competitors. If these barriers are sufficiently high, they may prevent substantial international consolidation of financial institutions. If these barriers are sufficiently low, efficiently managed foreign institutions may often be able to overcome cross-border disadvantages and operate relatively efficiently in many nations.

To put this issue into context, the Single Market Programme and European Monetary Union may be interpreted as reducing the efficiency barriers to cross-border consolidation within the EU, and within the subset participating in monetary union, respectively. These policies reduce or eliminate differences in currency, regulatory/supervisory structures, and explicit rules against foreign competitors from other EU nations, which should make it easier and less costly for efficient institutions to operate across international borders within the EU. However, these actions may not lower other barriers, such as distances between nations, differences in language and culture, or implicit rules against foreign institutions. It is an empirical issue whether these reductions in barriers are sufficient to allow a significant number of institutions to operate efficiently across borders in the EU.

This issue has a number of important implications. If domestically chartered institutions have significant efficiency advantages over institutions headquartered in other nations, then it is less likely that there will be substantial international consolidation, less of a single market in the EU, less international competition and pressure for lower prices, and fewer efficiency gains for the financial system from consolidation, all else held equal. If, instead, significant numbers of efficient institutions are able to overcome cross-border efficiency barriers and operate relatively efficiently across borders, then it is more likely that there will eventually be substantial international consolidation, more of a single EU market, more competition and pressure for lower 
prices, and more efficiency gains for the financial system in the long run, all else held equal.

Some extant research has compared the efficiency of foreign versus domestic institutions in the same nation or nations. Studies of banks operating in the U.S. typically found that foreign-owned banks are significantly less cost and profit efficient on average than domestic banks (e.g., DeYoung and Nolle 1996, Mahajan, Rangan, and Zardkoohi 1996). Some studies of operations in Europe found approximately equal cost efficiency between foreign and domestic banks (e.g., Vander Vennet 1996, Hasan and Lozano-Vivas 1998), and other research that used data on operations in many nations (not broken out by nation) generally found that foreign banks were less efficient than domestic institutions (Miller and Parkhe 1999, Parkhe and Miller 1999). One study of banks operating in the U.S. and four EU nations found that foreign banks were generally less profit efficient than domestic banks, but the results differed somewhat depending on the nation of origin and the home nation. In particular, foreign institutions headquartered in the U.S. were generally more efficient than domestic institutions in other nations, and foreign institutions were generally more efficient than domestic banks in Spain (Berger, DeYoung, Genay, and Udell 2000).

Table 2 shows the foreign versus domestic profit efficiency comparisons for four EU nations, taken from Berger, DeYoung, Genay, and Udell (2000). The underlying data are taken from the Fitch-IBCA database, which presents consistent accounting information for a sample of mostly large financial institutions in each country. The table shows the efficiency of domestic banks, all foreign banks, and banks headquartered in other EU nations for France, Germany, Spain, and U.K. For each of these four nations, efficiency is estimated only for foreign and domestic banks operating in that nation to avoid problems of trying to control for differences in economic environments across nations.

The results are consistent with most of the extant literature that found that foreign banks are usually less efficient on average than domestic banks, suggesting that barriers to cross-border operating efficiency offset most of any potential efficiency gains from cross-border consolidation in EU nations. In three of the four nations (all except Spain), banks headquartered in other EU nations and foreign banks as a whole are less efficient on average than domestic banks, although the differences are not statistically significant and are generally small (on the order of $5 \%$ of potential profits or less). In addition, in the two nations with the most EU-based foreign banks (France 
and Germany), the EU-based foreign banks also have lower average efficiency than foreign banks as a whole (a category which includes U.S.-owned banks).

Table 2 also suggests that banks from other EU nations comprise only a small proportion of the large banking organizations in all four home nations, consistent with the M\&A data shown in Table 1 above. If it were relatively easy for foreign banks to operate efficiently across international borders in the EU, a higher presence of banks from other EU nations might have been expected. Importantly, we also note that the EU banking organizations that did operate across international borders during this time period were likely to been among the most efficient at doing so. If there is a substantial increase in the proportion of institutions crossing these borders, the additional cross-border institutions are likely to be even less efficient on average than the first movers.

These results, should they continue to hold in the future, suggest that efficiency barriers to cross-border consolidation, such as distances between nations, differences in language and culture, or implicit rules against foreign institutions, may make it difficult to achieve anything close to a continent-wide or EU-wide single market for banking services. However, a number of strong caveats apply. We note that the data are for the 1992-1997 interval, before all of the effects of the Single Market Programme and European Monetary Union were incorporated. That is, to some degree, the findings reflect cross-border efficiency barriers such as differences in currency, regulatory/supervisory structures, and explicit rules against foreign competitors, which have been or will be reduced or eliminated by these two EU policies. There may also be significant efficiency benefits to crossborder consolidation that are realized in the home nations of the international banks, and so are not measured by the performance of their affiliates in the foreign nations, although some evidence in the literature suggests that this may not explain the findings (Berger, DeYoung, Genay, and Udell 2000). In addition, the future ability of financial institutions to exploit potential efficiency gains across borders may be strongly affected by the availability of electronic commerce and other technological changes. Furthermore, recent domestic megamergers in individual European nations may enhance the ability of these institutions to operate across international borders.

\section{Brief Summary}

International consolidation of financial institutions within Europe in general and within the EU in 
particular, has been relatively limited, despite efforts to create a single, efficient market for financial services in the EU. We hypothesize that this finding may result in large part because of efficiency barriers that make it difficult to own and operate a financial institution in another nation. These barriers including problems of managing and monitoring institutions from a distance; differences in language, culture, currency, and regulatory/supervisory structures across nations; and explicit or implicit rules against foreign competitors.

EU policies such as the Single Market Programme and European Monetary Union attenuate some but not all of these barriers. Specifically, these policies may reduce or eliminate differences in currency, regulatory/supervisory structures, and explicit rules against foreign competitors, but may not lower other barriers, such as distances between nations, differences in language and culture, or implicit rules against foreign institutions.

The available research and data are consistent with the hypothesis that barriers to cross-border operating efficiency offset most of any potential efficiency gains from cross-border consolidation. On average, banks based in other EU nations have lower measured efficiency than domestic banks and foreign banks headquartered outside the EU, although the differences are quantitatively small. These results, should they continue to hold in the future, suggest that the remaining barriers to efficient cross-border consolidation (distance, language, culture, implicit rules) may make it difficult to achieve anything close to a continent-wide or EU-wide consolidation into a single market for banking services. However, a number of strong caveats, some of which are detailed above, apply to predicting the future based on the conditions of the past. 


\section{$\underline{\text { References }}$}

Akhavein, Jalal D., Allen N. Berger, and David B. Humphrey. 1997. "The Effects of Bank Megamergers on Efficiency and Prices: Evidence from the Profit Function.” Review of Industrial Organization 12: 95-139.

Allen, Linda and Anoop Rai. 1996. "Operational Efficiency in Banking: An International Comparison." Journal of Banking and Finance 20: 655-672.

Berger, Allen N. 1998. "The Efficiency Effects of Bank Mergers and Acquisition: A Preliminary Look at the 1990s Data." In Bank Mergers \& Acquisitions, edited by Y. Amihud and G. Miller. Boston, MA. Kluwer Academic: 79-111.

Berger, Allen N., J. David Cummins, Mary A. Weiss, and Hongmin Zi. 2000. "Conglomeration Versus Strategic Focus: Evidence from the Insurance Industry." Board of Governors of the Federal Reserve System.

Berger, Allen N., Rebecca S. Demsetz, and Philip E. Strahan. 1999. "The Consolidation of the Financial Services Industry: Causes, Consequences, and Implications for the Future." Journal of Banking and Finance 23 (2-4): 135-194.

Berger, Allen N., and Robert DeYoung. 2000. "The Financial Performance of Cross-Regional Commercial Banks in the U.S.: Some Clues Regarding the Eventual Structure of a Consolidating Industry." Board of Governors of the Federal Reserve System.

Berger, Allen N., Robert DeYoung, Hesna Genay, and Gregory F. Udell. 2000. "The Globalization of Financial Institutions: Evidence from Cross-Border Banking Performance.” Brookings-Wharton Papers on Financial Services 3.

Berger, Allen N., Diana Hancock, and David B. Humphrey. 1993. "Bank Efficiency Derived from the Profit Function." Journal of Banking and Finance 17(2-3): 317-347.

Berger, Allen N., Gerald A. Hanweck, and David B. Humphrey. 1987. "Competitive Viability in Banking: Scale, Scope, and Product Mix Economies.” Journal of Monetary Economics 20(3): 501-520.

Berger, Allen N. and David B. Humphrey. 1992. "Megamergers in Banking and the Use of Cost Efficiency as an Antitrust Defense." Antitrust Bulletin, 37 (Fall), 541-600.

Berger, Allen N. and David B. Humphrey. 1997. "Efficiency of Financial Institutions: International Survey and Directions for Future Research.” European Journal of Operational Research 98: 175-212.

Berger, Allen N., David B. Humphrey, and Lawrence B. Pulley. 1996. "Do Consumers Pay for One-Stop Banking? Evidence from an Alternative Revenue Function.” Journal of Banking and Finance 20(9): 1601-1621.

Berger, Allen N. and Loretta J. Mester. 1997. "Inside the Black Box: What Explains Differences in the Efficiencies of Financial Institutions?" Journal of Banking and Finance 21: 895-947.

Bikker, Jacob A. and Johannes M. Groeneveld. 1998. "Competition and Concentration in the EU Banking Industry." Der Nederlandsche Bank. The Netherlands.

Boyd, John H., Stanley L. Graham, and R. Shawn Hewitt. 1993. "Bank Holding Company Mergers with Nonbank Financial Firms: Effects on the Risk of Failure.” Journal of Banking and Finance 17(1): 43-63. 
Cerasi, Vittoria, Barbara Chizzolini, and Marc Ivaldi. 1998. "Sunk Costs and Competitiveness of European Banks after Deregulation.” LSE Financial Markets Group Discussion Paper 290 (April).

Clark, Jeffrey and Thomas F. Siems. 1997. "Competitive Viability in Banking: Looking Beyond the Balance Sheet." Federal Reserve Bank of Dallas, Financial Industry Studies Working Paper No. 5-97.

Commission of the European Communities. 1988a. European Economy: The Economics of 1992. No. 35. Brussels: EU (March).

Commission of the European Communities. 1988b. The “Cost of Non-Europe” In Financial Services. Brussels: EU.

Cornett, Marcia Millon, and Hassan Tehranian. 1992. "Changes in Corporate Performance Associated with Bank Acquisitions.” Journal of Financial Economics 31(2): 211-234.

Cummins, J. David, Sharon L. Tennyson, and Mary A. Weiss. 1999. "Consolidation and Efficiency in the US Life Insurance Industry.” Journal of Banking and Finance 23(2-4): 325-357.

Cummins, J. David and Mary A. Weiss. 2000. "The Global Market for Reinsurance: Consolidation, Capacity, and Efficiency." Brookings-Wharton Papers on Financial Services 3.

Cummins, J. David and Hongmin Zi. 1998. "Comparison of Frontier Efficiency Methods: An Application to the U.S. Life Insurance Industry.” Journal of Productivity Analysis 10(2): 131-152.

Cybo-Ottone, Alberto and Maurizio Murgia. 1998. "Mergers and Shareholder Wealth in European Banking." Associazione Bancaria Italiana.

DeLong, Gayle L. 1999. "Domestic and International Bank Mergers: Shareholder Gains from Focusing versus Diversifying." Baruch College.

DeLong, Gayle L., Roy C. Smith, and Ingo Walter. 1998. “Global Merger and Acquisition Tables 1997.” Solomon Center, New York University.

DeYoung, Robert and Daniel E. Nolle. 1996. "Foreign-Owned Banks in the U.S.: Earning Market Share or Buying It?" Journal of Money, Credit, and Banking 28(4): 622-636.

European Commission. 1997. “Impact on Services: Credit Institutions and Banking.” The Single Market Review 2:4.

Fried, Harold O., C. A. Knox Lovell, and Suthathip Yaisawarng. 1999. "The Impact of Mergers on Credit Union Service Provision.” Journal of Banking and Finance 23(2-4): 367-86.

Goldberg, Lawrence G., Gerald A. Hanweck, Michael Keenan, and Allister Young. 1991. "Economics of Scale and Scope in the Securities Industry.” Journal of Banking and Finance 15: 91-107.

Hannan, Timothy H. and John D. Wolken. 1989. "Returns to Bidders and Targets in the Acquisition Process: Evidence from the Banking Industry.” Journal of Financial Services Research 3(1): 5-16.

Hasan, Iftekhar and Ana Lozano-Vivas. 1998. "Foreign Banks, Production Technology, and Efficiency: Spanish Experience.” Working Paper presented at the Georgia Productivity Workshop III. Athens, Georgia. 
Haynes, Michael and Steve Thompson. 1999. “The Productivity Effects Of Bank Mergers: Evidence From The UK Building Societies." Journal of Banking and Finance 23: 825-846.

Houston, Joel F. and Michael D. Ryngaert. 1994. “The Overall Gains from Large Bank Mergers.” Journal of Banking and Finance 18(6): 1155-76.

Hughes, Joseph P., William Lang, and Loretta J. Mester, and Choon-Geol Moon. 1996. "Efficient Banking Under Interstate Branching.” Journal of Money, Credit, and Banking 28(4): 1043-1071.

Hughes, Joseph P., William Lang, Loretta J. Mester, and Choon-Geol Moon. 1999. "The Dollars and Sense of Bank Consolidation." Journal of Banking and Finance 23(2-4): 291-324.

Kwan, Simon. 1998. "Securities Activities by Commercial Banking Firms' Section 20 Subsidiaries: Risk, Return, and Diversification Benefits.” Federal Reserve Bank of San Francisco Working Paper No. 98-10 (October).

Lang, Gunter and Peter Welzel. 1998. "Technology and Cost Efficiency in Universal Banking: A Thick Frontier Approach.” Journal of Productivity Analysis 10(1): 63-84.

Llewellyn, David. T. 1996. "Universal Banking and the Public Interest: A British Perspective.” In Universal Banking: Financial System Design Reconsidered, edited by Anthony Saunders, and Ingo Walter. Irwin Publishing: 161204.

Mahajan, Arvind, Nanda Rangan, and Asghar Zardkoohi. 1996. "Cost Structures in Multinational and Domestic Banking." Journal of Banking and Finance 20(2): 238-306.

McAllister, Patrick H. and Douglas A. McManus. 1993. "Resolving the Scale Efficiency Puzzle in Banking." Journal of Banking and Finance 17(2-3): 389-405.

Mester, Loretta J. 1993. “Efficiency in the Savings and Loan Industry.” Journal of Banking and Finance 17(2-3): 267286.

Miller, Stewart R. and Arvind Parkhe. 1999. "Home-Country Environment as a Source of International Competitiveness: An Analysis of the Global Banking Industry.” Michigan State University.

Molyneux, Philip, D.M. Lloyd-Williams, and John Thornton, 1994. "Competitive Conditions in European Banking." Journal of Banking and Finance 18(3): 445-459.

Parkhe, Arvind and Stewart R. Miller. 1999. "Is There a Liability of Foreignness in Global Banking? An Empirical Test of U.S. Banks' X-Efficiency.” Michigan State University.

Resti, Andrea. 1998. "Regulation Can Foster Mergers, Can Mergers Foster Efficiency? The Italian Case.” Journal of Economics and Business 50(2): 157-169.

Rhoades, Stephen A. 1998. "The Efficiency Effects of Bank Mergers: An Overview of Case Studies of Nine Mergers." Journal of Banking and Finance 22(3): 273-291.

Saunders, Anthony and Ingo Walter. 1994. Universal Banking in the United States: What Could We Gain? What Could We Lose? Oxford University Press. 
van Beek, Luuk and Alireza Tourani Rad. 1997. "Market Valuation of Bank Mergers in Europe" Financial Services. Amsterdam.

Vander Vennet, Rudi. 1996. "The Effect of Mergers and Acquisitions on the Efficiency and Profitability of EC Credit Institutions." Journal of Banking and Finance 20(9): 1531-1558.

Vander Vennet, Rudi. 1998. "Causes and Consequences of EU Bank Takeovers." In The Changing European Landscape, edited by Sylvester Eijffinger, Kees Koedijk, Marco Pagano, and Richard Portes, Centre for Economic Policy Research. Brussel, Belgium: 45-61.

Vander Vennet, Rudi. 1999. "Cost and Profit Dynamics in Financial Conglomerates and Universal Banks in Europe." University of Ghent. Belgium. 
Table 1

Values of Target Institutions in European Financial Services M\&A Activity from 1985 to 1997

\begin{tabular}{|c|c|c|c|c|c|c|c|c|c|}
\hline & \multicolumn{3}{|c|}{$\begin{array}{c}\text { Panel A: } \\
\text { Domestic M\&As within } \\
\text { European Nations }\end{array}$} & \multicolumn{3}{|c|}{$\begin{array}{c}\text { Panel B: } \\
\text { Intra-Europe } \\
\text { International M\&As }\end{array}$} & \multicolumn{3}{|c|}{$\begin{array}{l}\text { Panel C: } \\
\text { Europe-Non Europe } \\
\text { International M\&As }\end{array}$} \\
\hline & \multicolumn{9}{|c|}{ Target Institution } \\
\hline $\begin{array}{l}\text { Acquiring } \\
\text { Institution }\end{array}$ & Banks & Securities & Insurance & Banks & Securities & Insurance & Banks & Securities & Insurance \\
\hline $\begin{array}{l}\text { Commercial } \\
\text { Banks }\end{array}$ & $\begin{array}{c}89 \\
(36.0 \%)\end{array}$ & $\begin{array}{c}9 \\
(3.6 \%)\end{array}$ & $\begin{array}{c}20 \\
(8.1 \%)\end{array}$ & $\begin{array}{c}15.0 \\
(17.9 \% \\
)\end{array}$ & $\begin{array}{c}8.7 \\
(10.4 \%)\end{array}$ & $\begin{array}{c}0.4 \\
(0.5 \%)\end{array}$ & $\begin{array}{c}14.5 \\
(14.5 \%)\end{array}$ & $\begin{array}{c}4.3 \\
(4.3 \%)\end{array}$ & $\begin{array}{c}0.3 \\
(0.3 \%)\end{array}$ \\
\hline $\begin{array}{l}\text { Securities } \\
\text { Firms }\end{array}$ & $\begin{array}{c}23 \\
(9.3 \%)\end{array}$ & $\begin{array}{c}19 \\
(7.7 \%)\end{array}$ & $\begin{array}{c}24 \\
(9.7 \%)\end{array}$ & $\begin{array}{c}4.3 \\
(5.1 \%)\end{array}$ & $\begin{array}{c}5.8 \\
(6.9 \%)\end{array}$ & $\begin{array}{c}1.1 \\
(1.3 \%)\end{array}$ & $\begin{array}{c}15.6 \\
(15.6 \%)\end{array}$ & $\begin{array}{c}15.9 \\
(15.9 \%)\end{array}$ & $\begin{array}{c}12.9 \\
(12.9 \%)\end{array}$ \\
\hline $\begin{array}{l}\text { Insurance } \\
\text { Companies }\end{array}$ & $\begin{array}{c}11 \\
(4.4 \%)\end{array}$ & $\begin{array}{c}6 \\
(2.4 \%)\end{array}$ & $\begin{array}{c}46 \\
(18.6 \%)\end{array}$ & $\begin{array}{c}11.2 \\
(13.4 \% \\
)\end{array}$ & $\begin{array}{c}0.3 \\
(0.4 \%)\end{array}$ & $\begin{array}{c}37.0 \\
(44.2 \%)\end{array}$ & $\begin{array}{c}1.0 \\
(1.0 \%)\end{array}$ & $\begin{array}{c}3.1 \\
(3.1 \%)\end{array}$ & $\begin{array}{c}32.7 \\
(32.6 \%)\end{array}$ \\
\hline
\end{tabular}

Sources: DeLong, Smith and Walter (1998), Berger, Demsetz, and Strahan (1999), and Securities Data Company. The main number shown in each entry is the sum of the equity values (in billions of U.S. dollars) of the target institutions. The number in parentheses is the percentage of the total (these sum to 100 for each $3 \times 3$ matrix). 
Table 2 - Foreign versus Domestic Bank Profit Efficiency in Four EU Nations

\begin{tabular}{|lcccc|}
\hline \multicolumn{1}{c}{ Home country: } & France & Germany & Spain & UK \\
\hline All domestic banks & 0.4459 & 0.5404 & 0.6596 & 0.6833 \\
& 158 & 121 & 60 & 63 \\
& 0.0214 & 0.0231 & 0.0232 & 0.0270 \\
\hline All foreign banks & 0.4308 & 0.4946 & 0.7138 & 0.6373 \\
& 57 & 85 & 16 & 61 \\
\hline EU-based foreign banks & 0.0279 & 0.0240 & 0.0340 & 0.0273 \\
& 0.4082 & 0.4545 & $0.7465^{*}$ & 0.6627 \\
& 34 & 23 & 11 & 9 \\
& 0.0327 & 0.0446 & 0.0395 & 0.0948 \\
\hline
\end{tabular}

Each cell contains: mean efficiency, number of banks, standard error.

* indicates cell mean is significant different from the domestic mean at the 10 percent level.

Alternative profit efficiency is measured using the "distribution-free" approach using data on large banks operating in each nation (separately) over 1992 through 1997.

Sources: Berger, DeYoung, Genay, and Udell (2000), Fitch-IBCA's Bankscope database. 